\title{
DFG purchases Emerald Archive for German Research Community
}

UNITED KINGDOM, March 2007 - Emerald Group Publishing Limited, a leading publisher of academic and professional literature in management, library services and engineering is pleased to announce an agreement with the DFG (Deutsche Forschungsgemeinschaft) which will entitle registered users in Germany to access all Emerald journals that were owned and published between 1st January 1994 and 31st December 2005. The agreement, negotiated by the Universitäts-und Stadtbibliothek Köln (USB) and Informationszentrum Sozialwissenschaften (IZ), means that everyone in Germany can access Emerald content if they are students or faculty of higher education institutions, or are members of an academic library, research institution or governmental institution. Individual access is permitted via usernames and passwords subject to permanent residence in Germany.

The licence will cover the 339 universities in Germany, and will provide access to Emerald's flagship journals, including Management Decision, European Journal of Marketing, Library Hi-Tech, Library Management and Soldering \& Surface Mount Technology. Jenny Pickles, Head of Business Development at Emerald says, "We are delighted that as a result of this agreement with the DFG, researchers throughout Germany will now have unlimited access to Emerald's prestigious journal archives to support their work and career development. We look forward to working in partnership with our German colleagues to continue to provide enhanced, up-to-date content on an ongoing basis".

The Deutsche Forschungsgemeinschaft (DFG) is the central public funding organization responsible for promoting research in Germany. Its activities focus on funding research projects carried out by scientists and academics working at universities or research institutes. The work of the DFG serves all branches of science and the humanities to reflect its role as the self-governing organisation of German science and research. DFG membership is made up of German universities, non-university research institutions, scientific associations as well as the Academies of Science and Humanities Eligible German organizations may request access to the Emerald archive via www.Nationallizenzen.de

\section{About Informationszentrum Sozialwissenschaften (IZ)}

Social Science Information Centre, http://www.gesis.org

The Social Science Information Centre (IZ) collects and disseminates information on the current state of research and literature in the social sciences in the German-speaking countries as well as on the social science research in Eastern Europe. In order to obtain, process and use the information in an efficient way, IZ carries out research \& development in information science and in information technology. 


\section{About Universitäts- und Stadtbibliothek Köln (USB)}

University and City Library of Cologne, http://www.ub.uni-koeln.de

The University and City Library of Cologne (USB) is the central universal library of the University of Cologne, the largest university in Germany with almost 50,000 students. In the field of economics and business administration there are about 7,500 students.

The USB has a special collection in management / business administration. For this field - funded by the Deutsche Forschungsgemeinschaft DFG - the library provides students and academics all over Germany via inter-library-loan and document delivery with the literature they need. The special collection has a main focus on non-German material and grey literature from Germany, Austria and Switzerland.

The main platform for the management collection is the Virtual Library for Management and Economics EconBiz (together with the Deutsche Zentralbibliothek für Wirtschaftswissenschaften (ZBW) in Kiel). EconBiz contains a subject guide for more than 16,000 internet resources, calendar of events, full text and other information services (free of charge). http://www.econbiz.de EconBiz has a meta-search that leads you to all kinds of printed and online material in business and economics.

http://www.emeraldinsight.com 